\title{
Putting a Face to a Name
}

\section{Visualising Human Rights}

\author{
VERA MACKIE \\ UNIVERSITY OF WOLLONGONG
}

What would it mean to 'visualise' human rights? Can an abstract concept like 'human rights' really be presented in pictorial form? What is at stake in such a project of visualisation for the producers and consumers of texts? The visual, it seems, is important in various modes of communicating about human rights, whether on the internet, in broadcast media, in documentary films, in drama, in pamphlets, posters, fliers, or even, as we shall see below, in coffee table books. It might be thought that the book as a mode of communicating about human rights would be superseded in the age of new media. A visit to the United Nations headquarters in New York, however, would belie this view. The building itself can be read as a massive text. In carefully guided tours, the visitor is invited to read meaning from the row of national flags outside, the massive modernist building by Le Corbusier (1887-1965) and Oscar Niemeyer (1907-2012), the layout of the General Assembly and Security Council meeting rooms, the artworks and sculptures, and from instructive dioramas and wall panels. In the basement of the building is a huge bookshop, with books on every aspect of the United Nations system, the associated documents, charters and treaties, biographies of the heroes of human rights advocacy, testimonies of those who have suffered human rights abuses and souvenirs of the visit to the United Nations building itself. One can also purchase children's books that convey the 
content of the Universal Declaration of Human Rights in visual form. The physical bookshop is augmented by an on-line bookshop with an extensive catalogue. ${ }^{1}$

In this article, I focus on just one such publication which attempts to deal with human rights issues in an accessible format, Walter Kälin, Lars Müller and Judith Wyttenbach's book, The Face of Human Rights. ${ }^{2}$ The book is interesting in its attempt not just to educate through verbal means, but also through its use of the visual. My discussion will mainly focus on this one text and some of its intertexts, in an attempt to develop a mode of analysis of such visual texts, a strategy of reading and viewing which can potentially assist us in thinking about effective modes of communication.

In conducting this analysis, I recognise that human rights advocacy involves more than just stating the facts, or even just providing a narrative in a realist mode. Several commentators have noted the importance of narrative in human rights advocacy, ${ }^{3}$ while others have explored the role of the arts, documentaries, theatre and new social media. ${ }^{4}$ I am interested in analysing narrative and representational strategies, from a consciousness that texts work not only through vocabulary and propositional content, but also through discursive positioning. It is necessary to look at the structure of texts, the contents of texts, and the narrative strategies and discursive frameworks which inform them. ${ }^{5}$ Similar points can be made about photography, which must be analysed in terms of the specific representational possibilities of the visual medium. ${ }^{6}$ We also need to be sensitive to different modes of display. The experience of looking at a photograph (or photographs) will be different depending on whether it is seen on a gallery or museum wall, on an instructional wall panel, as a postcard or photographic print which can be held in the hand, in a frame, as a poster, in a slide show, in a power point presentation or in a book.

-VISUALISING HUMAN RIGHTS

In The Face of Human Rights various textual explanations of human rights are juxtaposed with a series of photographs. The editors' stated intent is to show what they call the 'face' of human rights or, in other words, to use the resources of visual culture to contribute to the discussion of human rights. Over four hundred photographs are dispersed among the text of the 720-page volume. Some are singleor double-page spreads, and some are arranged on foldout pages to illustrate 
particular issues. Some series of photographs are clearly illustrative; at other times, there is an implicit narrative constructed through concatenation and juxtaposition. The feel of this substantial volume is reminiscent of the 'coffee table' books from such international art publishers as Phaïdon. ${ }^{7}$ The editors set out their project in the following terms:

This book attempts to visualise all these dimensions of human rights. Its photographs celebrate the enjoyment of human rights, i.e. life in freedom and dignity, in its full richness and across cultures. The accompanying texts document, explain and detail the human rights standards as defined by international law and applied in practice. At the same time we want to illustrate and document how human rights are violated. The examples from South and North, West and East show that no state and no society is totally immune to the temptation to disregard the rights of others when this serves one's own purposes. Finally we want to show what the international community, international or local non-governmental organizations working at different levels do to prevent, sanction and redress human rights violations. ${ }^{8}$

In many ways, this project has echoes of the exhibition 'The Family of Man' held at the Museum of Modern Art (MOMA) in New York in 1955, even though six decades separate the two projects. 'The Family of Man', which was conceived by photographer and curator Edward Steichen (1879-1973) and supported by the Ford Foundation, took a similarly global view. It consisted of 508 photographs from 68 countries by 273 photographers, depicting 'subject matter ranging from babies to philosophers, from the kindergarten to the university, from primitive [sic] peoples to the Councils of the United Nations'. ${ }^{9}$ The exhibition travelled to several countries and now has a permanent home in Luxembourg, Steichen's country of birth. 'The Family of Man' has also been reproduced in book format and, until the development of the internet, it was probably through the book that most viewers were able to see the photographs. As for the exhibition, it has been critiqued thoroughly over the last sixty-odd years, starting with Roland Barthes' trenchant critique of its 1956 French incarnation as 'La Grande Famille des Hommes' (The Great Family of Man, emphasis added). ${ }^{10}$

Barthes' essay opens with a deceptively simple account of the exhibition: 
A big exhibition of photographs has been held in Paris, the aim of which was to show the universality of human actions in the daily life of all the countries of the world: birth, death, work, knowledge, play, always impose the same types of behaviour; there is a Family of Man.11

The essay itself, however, is an attempt to challenge the assumptions of humanism and universalism which underpin the exhibition:

Any classic humanism postulates that in scratching the history of men [sic] a little, the relativity of their institutions or the superficial diversity of their skins (but why not ask the parents of Emmet Till, the young Negro assassinated by the Whites, what they think of The Great Family of Man?), one very quickly reaches the solid rock of a universal human nature. ${ }^{12}$

Barthes is referring to Emmet Till, an African-American teenager who was murdered in Mississippi in 1955 at the age of fourteen, after he had been accused of flirting with a white woman. At his funeral, his mutilated body was shown in an open casket. Photographs of Till's body circulated widely and served to draw attention to problems in race relations in the southern states of the United States. Barthes' seemingly parenthetical comment on Emmet Till in fact goes to the heart of his essay. The story of Emmet Till draws attention to the structured inequalities which are masked by the rhetoric of universalism. Press photography was one of the means by which Emmet Till's story was brought to global attention, and this reminds us of continued debates on the ethics of display and the ethics of looking. ${ }^{13}$ Barthes reminds us that all photographs exist in history, a history which, he argues, is deflected in the exhibition. ${ }^{14}$ As I will argue in more detail below, photographs also need to be read in terms of their intertextual relationship with other images and other texts. Furthermore, as Barthes suggests, what is not shown can be just as important as what is seen.

More recently, Fred Turner has re-examined Steichen's exhibition, focusing on the three-dimensional and embodied experience of the original installation at MOMA. Turner argues that the exhibition was engaged in producing a particular form of citizenship and governmentality, and that 'even as it challenged the hierarchies of totalitarianism, the exhibition modelled the emergence of a society whose citizens were to manage themselves in terms set by the systems within which they lived-and by the experts who developed those systems'. ${ }^{15}$ 
The editors of The Face of Human Rights say they have chosen photographs which 'celebrate the enjoyment of human rights, i.e. life in freedom and dignity, in its full richness and across cultures'.16 This echoes the aims of Steichen, who worked on 'The Family of Man' after curating two propaganda exhibitions in support of war efforts. He commented, 'I came to the conclusion that I had been working from a negative approach, that what was needed was a positive statement on what a wonderful thing life was, how marvellous people were, and, above all, how alike people were in all parts of the world'.17

Both 'The Family of Man' and The Face of Human Rights display hundreds of photographs from around the globe, arranged in thematic clusters which often juxtapose similar scenes from different local contexts (such as wedding ceremonies, classrooms or children playing). Both texts gesture towards universalism-the discourse of 'the family of Man' in the earlier text and the discourse of 'human rights' in the later text.18 In 1955, the reference points were the Holocaust, the recent war with Japan and Germany, the recent deployment of nuclear weapons, the continued threat of nuclear conflict and the decade-old United Nations Organisation. ${ }^{19}$ By the early twenty-first century, when The Face of Human Rights was published, the discourse of 'human rights' had moved to centre stage. The global machinery of the human rights system had expanded, with the Universal Declaration of Human Rights and the Genocide Convention of 1948 having been supplemented by an array of declarations, conventions, treaties, committees, commissions and international courts. ${ }^{20}$ Since the first decade of the twenty-first century, however, human rights discourse has been overshadowed by militarisation, securitisation and surveillance after the terrorist attacks on 9 September 2001 and the ensuing 'war on terror'. These developments cast a shadow over The Face of Human Rights.

\section{—NARRATING HUMAN RIGHTS}

The text of the book includes the relevant human rights conventions and declarations, explication of the different generations of human rights, verbal portraits of human rights activists, extracts from such texts as Ryszard Kapuscinski's (1932-2007) The Emperor and Susan Sontag's (1933-2004) Regarding the Pain of Others, and an account of Death Row in Huntsville, Texas. ${ }^{21}$ The inclusion of the essay on Death Row in Texas, and the inclusion of photographs from the United 
States, the United Kingdom and Europe as well as the third world helps dispel any impression that human rights issues are largely third world issues. This reinforces the editors' point that, 'no state and no society is totally immune to the temptation to disregard the rights of others when this serves one's own purposes'.22 The Face of Human Rights also attempts a complete coverage of all of the human rights issues addressed in the major UN declarations and conventions. The issue of sexual orientation is included, too-an issue which is still not dealt with adequately in the UN system. An excerpt from the decision of the UN Human Rights Commission in the case of Young v. Australia is reproduced, under the heading 'No Person Shall be Discriminated against because of their Sexual Orientation'. Other blocks of text concern homophobia in South Africa; multiple discrimination against persons living with HIV/AIDS; and a quote from Boeuthius (480-525), 'Who would give a law to lovers? Love is unto itself a higher law.' On the facing page are photographs of two women in what they call a 'holy union',23 and of two elderly men in identical shirts and shorts in a gay pride march in New York (Figure 1).24 These photographs presumably come under the category of 'the enjoyment of human rights, i.e. life in freedom and dignity, in its full richness and across cultures'.25

An early spread uses a graphic to outline the basic human rights, under the heading 'Dimensions of Life and the Protection of Human Rights'. The graphic takes the form of a spiral-a black spiral line on a grey background. From the centre to the margins of the spiral are a series of keywords and phrases. At the centre, there is 'Human Existence/ THE RIGHT TO LIFE'. As we move out, there are 'Identity of the human person/ PROHIBITION OF DISCRIMINATION', 'Adequate standards of living/ THE RIGHT TO FOOD/ THE RIGHT TO HEALTH/ THE RIGHT TO HOUSING', 'Private sphere/ THE PROTECTION OF PRIVATE LIFE', 'Intellectual and spiritual life/ THE FREEDOM OF THOUGHT AND BELIEF/ THE RIGHT TO EDUCATION', 'Economic life/ THE RIGHT TO WORK/ THE PROTECTION OF PROPERTY', 'In the hands of the state/ FAIR TRIAL AND PROHIBITION OF TORTURE', 'Political participation/ POLITICAL RIGHTS AND FREEDOM OF EXPRESSION', and finally 'Displacement, flight and exile/ THE RIGHTS OF REFUGEES AND DISPLACED PERSONS'. This is a simple graphic depiction of the concerns of the book as a whole, and is repeated at the start of each thematic section. The spiral recapitulates the different 'generations' of human rights: first-generation rights to security, property and political participation; second- 


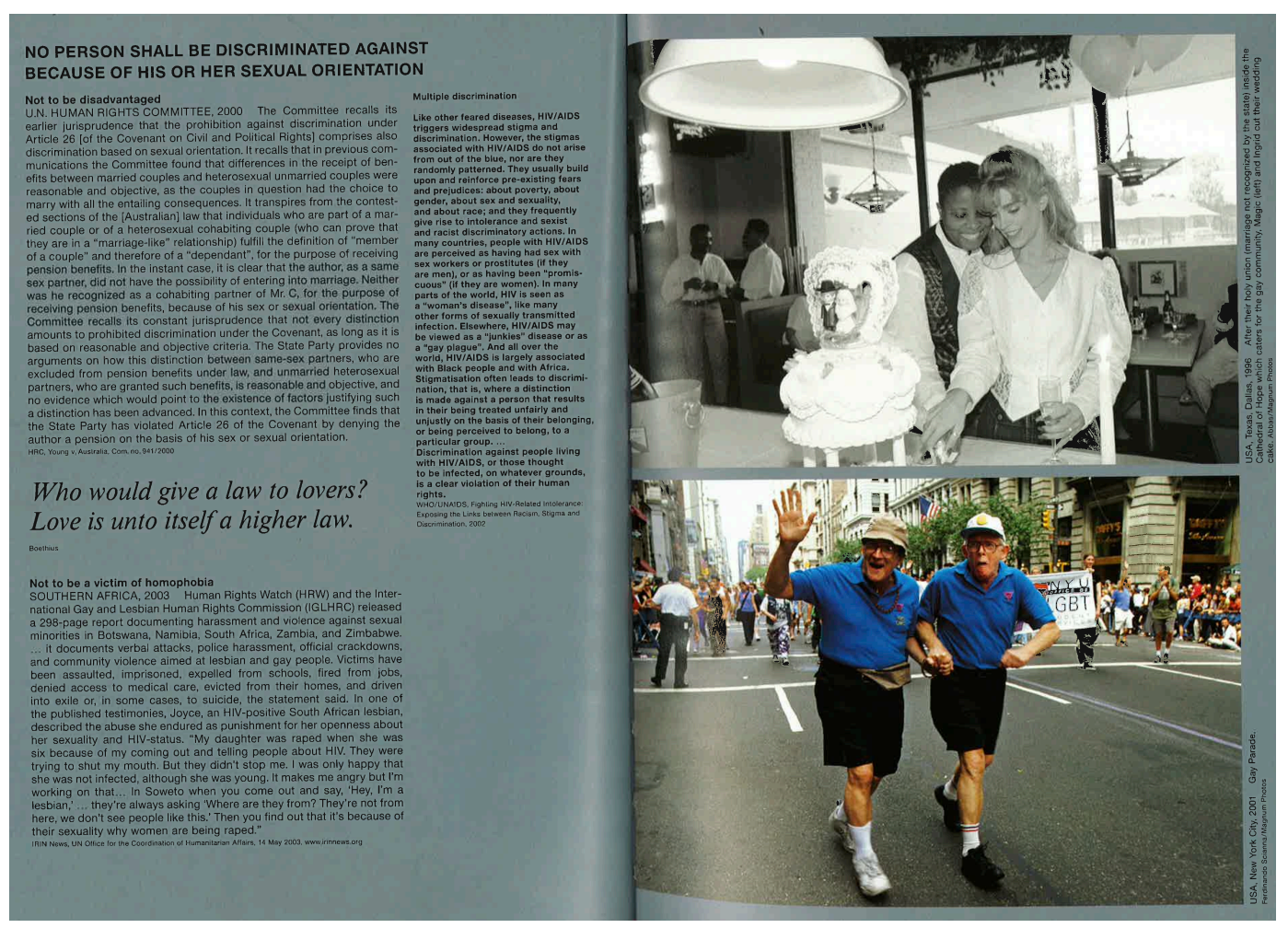

Figure 1: Abbas, Holy Union, Dallas, Texas, 1996 (right, top); Ferdinando Scianna, Gay Pride Parade, New York City, 2001 (right, bottom); double-page spread from Walter Kälin, Lars Müller and Judith Wyttenbach (eds), The Face of Human Rights, pp. 138-9

Source: reproduced with permission of Lars Müller Publishers, Magnum Photos and Snapper Media.

generation rights to welfare, education and leisure; and third generation rights to national self-determination, a clean environment, and indigenous rights. ${ }^{26}$ This is on the recto page. The verso page has a photograph of a family in an art gallery in Germany. They are gazing at a monumental painting which appears to be a battle scene, a tumble of bodies and horses. The meaning of this juxtaposition is left up to the imagination of the reader (Figure 2). ${ }^{27}$

An essay on health care in Afghanistan bears the curious title 'Visualizing Women's Health Care in Afghanistan', when in fact the essay is a verbal explanation, with no explicit discussion of what it might actually mean to 'visualise' such an issue. ${ }^{28}$ This is one of the frustrations of the book. As someone who has spent much of their time analysing visual culture and who is sympathetic to the power to 


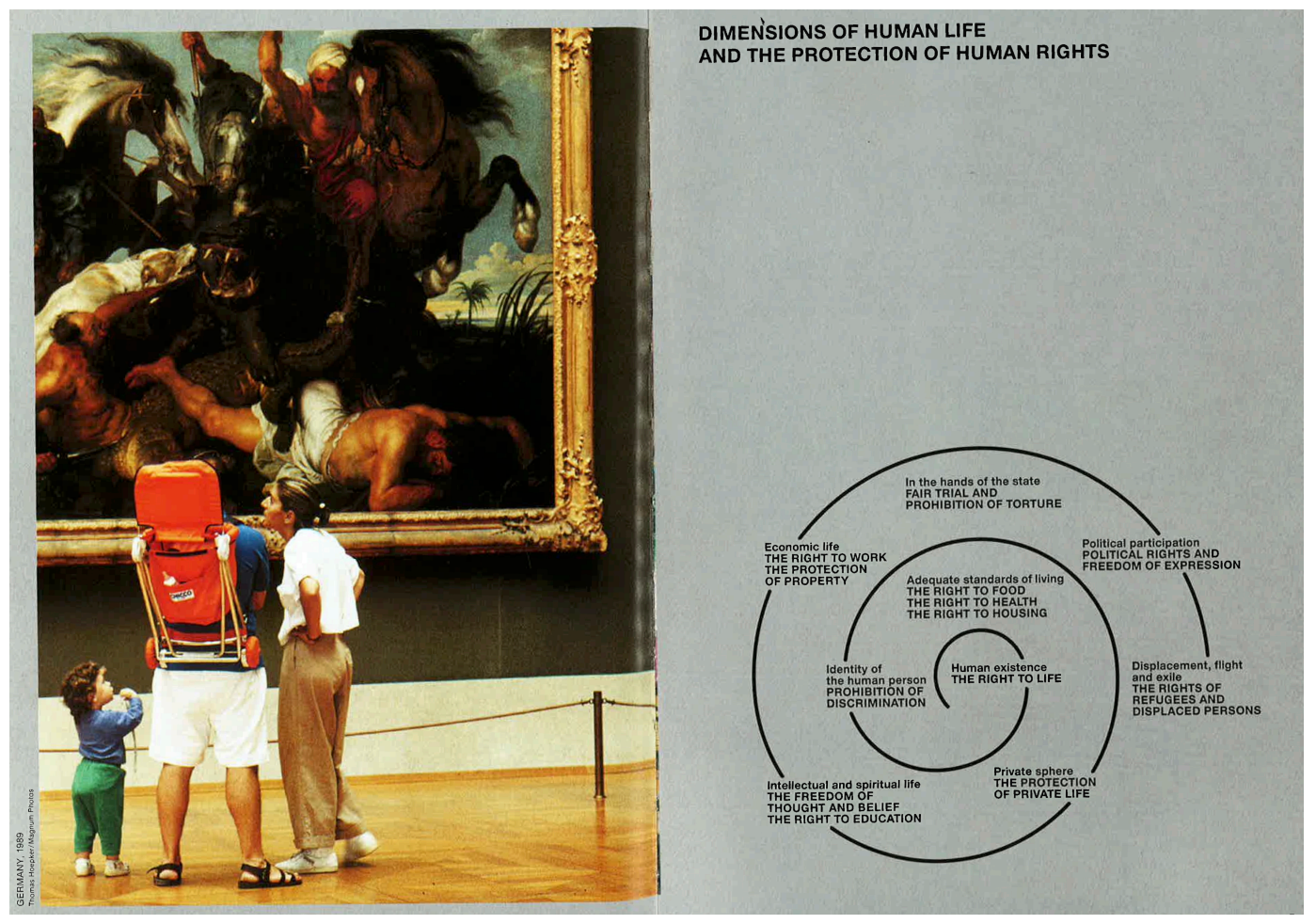

Figure 2: Thomas Hoepker, People visit the Alte Pinakothek Museum, Munich, Bavaria, Germany, 1989

Source: Double-page spread from Walter Kälin, Lars Müller and Judith Wyttenbach (eds) The Face of Human Rights, pp. 6-7; reproduced with permission of Lars Müller Publishers, Magnum Photos and Snapper Media

communicate through visual as well as verbal means, the lack of a clear articulation of what it means to communicate through the visual seemed like a missed opportunity. Similarly, I felt the lack of a clear articulation of why this means of communication is particularly suited to human rights advocacy. This contrasts with the strong vision of Steichen and his collaborators in curating 'The Family of Man'. Commentators have noted the strong narrative constructed through the viewer's temporal and physical progression through the exhibition, and the use of the theories of Bauhaus refugee designer Herbert Bayer (1900-1985) in designing the exhibition space.

Although The Face of Human Rights appears only in book format rather than the three-dimensional space of the museum, its scope is comparable with 'The Family of Man'. It is also necessary to remind ourselves that, although photographs are two- 
dimensional images, books are three-dimensional objects. Looking at books is an embodied experience in time and three-dimensional space. Rather than a simple opposition between museum and book, we rather have different kinds of embodied experience. As the pages of the book unfold through time and space, the experience of the reader and viewer is to some extent guided by the choices of the editors in the juxtaposition and serial ordering of image and text. The editors' choices, however, do not completely determine the reader's experience. A reader can leaf through from front to back, back to front, randomly, or in other sequences with reference to the index and table of contents.

\section{-Visual narRatives}

Some series of photographs are clearly illustrative. A section on education is surrounded by photographs of classrooms from around the world. ${ }^{29} \mathrm{~A}$ text on the 'right to marry' is surrounded by photographs of a mass wedding ceremony in South Korea, and examples of ceremonies from (Greek) Cyprus, Trinidad and Tobago, Iran, Japan, the United States of America and Mexico. ${ }^{30}$ Same-sex partnerships, however, are illustrated in a separate section on discrimination due to sexual orientation, unwittingly reinforcing heteronormativity through treating same-sex partnerships as a special category. ${ }^{31}$ These series of photographs of wedding ceremonies, children studying, people shopping or people attending demonstrations might remind the viewer of Barthes' criticism of the depiction of birth and death in 'The Family of Man': 'if one removes History from them, there is nothing more to be said about them; any comment about them becomes purely tautological'. 32

Another page shows parliamentary debating chambers from Austria, Germany, Iraq and the United Kingdom:

AUSTRIA, Vienna, 8 February 2000 Parliamentary deputies gather for their

first session after a new government was sworn in the week before. Rudi Biaha/AP

GERMANY, Berlin, 12 September 2001 Members of the German parliament stand as they hold a minute of silence for the victims of the terrorist attacks in the United States. Markus Schreiber/AP 
IRAQ, Irbil, 31 October 2002 Kurdish members of parliament sit during the fourth session of the regional parliament in Irbil. Hasan Sarbakhshian/AP

UK, London 27 January 2004 House of Commons during the second reading of the Higher Education Bill which introduces controversial university tuition fees. Keystone ${ }^{33}$

Most readers will immediately understand the reference to the German parliament's silence in memory of the victims of the terrorist attacks of 9 September 2001. A deeper knowledge of history would be necessary in order to decode the significance of the Kurdish membership in the regional parliament in 2002. The Kurds are an ethnic group who do not have one homeland, but who reside in Turkey, Iraq, Iran, and Syria. Within Iraq, they gained access to a regional parliament in 1992. The date of the photograph is 2002, one year before the US invasion of Iraq. The caption provides little sense of this history, and no indication of the fate of the Kurds after the US invasion. Or, is the photograph just there as one of a random set of photographs of parliaments, perhaps suggesting a universal aspiration for democracy?

In other cases the reader might infer a narrative through looking at the juxtaposition of images from page to page. The first photograph in the book shows a woman and child walking through a marketplace. The street scene behind them is slightly out of focus, with the woman and child in full focus, making them the centre of attention. Although there are two figures, the photograph is cropped so that the woman's face is not seen. It is thus the girl's face which draws the viewer's attention. The implied viewpoint in the picture is that of the girl. If this were a scene in a movie we would expect the next shot to focus on what is being looked at by the girl. In the static photographic medium, however, we follow the gaze of the girl to another part of the photograph. She looks sideways at piles of ripe red tomatoes on a market stall, also in full focus. The lush red of the tomatoes contrasts with the pale green of the girl's dress and the pale blue denim of the woman's overalls (Figure 3). I imagine that her gaze is one of desire, that she is perhaps poor and hungry, but I have no means of verifying this. The figures are not named-the only information provided is that this is Nicaragua in 2002. 


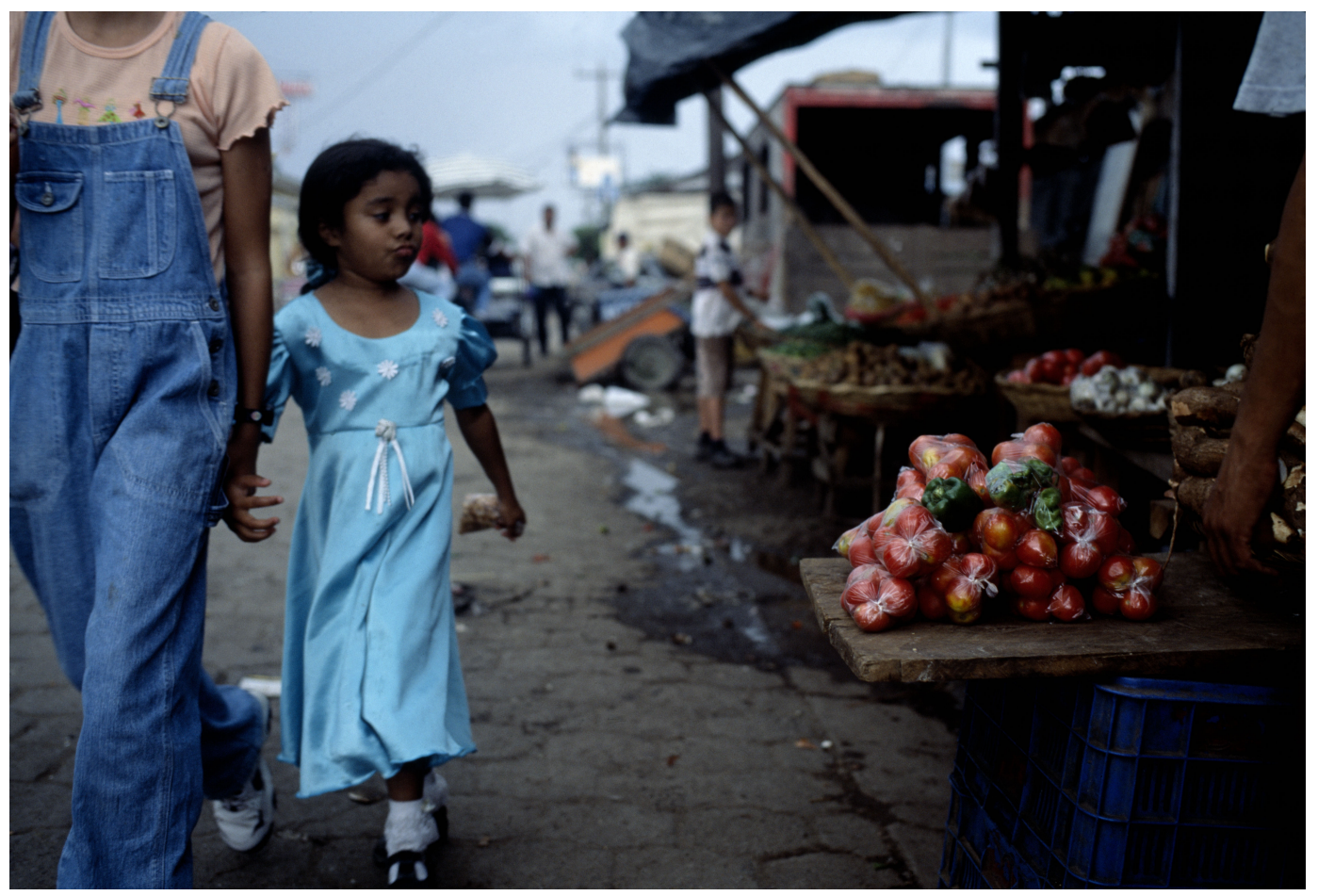

Figure 3: David Alan Harvey, Nicaragua, 2002

Source: Reproduced with permission of Magnum Photos and Snapper Media

A few pages later there is a photograph of some senior citizens in the United States in a casino, playing roulette while dressed in garish clothes and wearing artificial leis. ${ }^{34}$ The bright colours remind me of the earlier market scene, leading me to construct a narrative of wealth contrasted with poverty. The location of these photographs in a book on human rights reminds me of the 'first generation' rights which address basic human needs for shelter and sustenance.

Leafing further through the book I encounter another market scene. It is the aftermath of a bombing in a market in Kosovo in 1999, where bloodied bodies are surrounded by piles of market vegetables in disarray. This scene in Kosovo takes on a dissonant relationship with the earlier market scene. If I turn back to the Nicaraguan market scene, the tomatoes now seem to have taken on the colour of blood. ${ }^{35}$ The photograph of the aftermath of the Kosovo bombing is one of a small number of explicit depictions of the effects of violence in the book. ${ }^{36}$ Generally, the editors have exercised tact in keeping the visual representations of violence to a minimum, preferring to suggest violence by other means. 
At other times, a narrative is built up through concatenation, as in the extended series of similar photographs of wedding ceremonies, classrooms or parliamentary chambers noted above. ${ }^{37}$ There is an extended series of photographs of death chambers and prison cells. No human figures appear in any of these photographs, so that the viewer is prompted to imagine the executions which took place there. The captions remind us that states around the world are engaged in perpetrating violent acts against their citizens. Because the meaning of these photographs would be opaque without explanation, however, the captions are quite wordy. Even with these captions, however, as with the abovementioned photographs of parliaments, a knowledge of history is necessary to decode the photographs and text.

USA, Texas, Huntsville 1992 Lethal injection chamber, Texas state prison. 'The Omega Suites', Lucinda Devlin ${ }^{38}$

IRAQ, Baghdad 2003 Ropes used for hanging political prisoners in the death row of the notorious Abu Ghraib prison. Abbas/Magnum Photos ${ }^{39}$

CHILE, Santiago, 1998 In the National Stadium, thousands were imprisoned and many executed during the 1973 coup d'état. Patrick Zachmann/ Magnum Photos 40

USA, Virginia, Jarratt, 1991 Final holding cell in Greensville correctional facility. 'The Omega Suites', Lucinda Devlin ${ }^{41}$

In this series of photographs, in a section titled 'Is the state entitled to kill?', there is an implication of parallelism between the state-sanctioned administration of the death penalty in the United States, and the hangings and executions carried out in Chile in 1973 and Iraq in the years before 2003. The photograph of Abu Ghraib prison is dated 2003, suggesting it was taken soon after the US invasion of Iraq. The book appears, then, to have been in production before the controversy about photographs of US soldiers torturing Muslim prisoners in the very same Abu Ghraib prison emerged in April 2004.

While some implicit narratives are constructed through the juxtaposition and concatenation of images within the book, other photographs are likely to be read with reference to intertextual links. They remind the reader of photographs and texts from elsewhere. The abovementioned photograph of two women cutting their 
wedding cake reminds us of all of the similar photographs of heterosexual wedding celebrations. It gains meaning from its recognisability as a wedding photograph, but also in its distinctiveness in having two partners of the same sex.42

-FRAMING THE FACE

Most of the photographs in the book depict people, as individuals or in groups. The photographs are in realist and documentary style. ${ }^{43}$ That is, we see a series of faces, a few with names, but most un-named. ${ }^{44}$ The use of the word 'face' in the title of the book suggests an attempt to personalise, or personify, human rights issues. ${ }^{45}$ Once again, there are some echoes of the 'Family of Man' project, with its 'alphabet here and a multiplication table of living breathing human faces'. In a prologue to the 'Family of Man', Carl Sandburg asserts that faces often 'speak what words can never say'. 46

The face is the proof of humanness. In interpersonal communication, the face is the site where we recognise the uniqueness of our interlocutor. When we look at a photograph of a human face, we feel a similar sense of connectedness, most powerfully when the person being photographed has looked directly at the camera, and who now seems to look into our eyes. Otherwise, we will attempt to follow the gaze of the photographic subject, as in the market scene discussed above, where we immediately follow the child's gaze to the pile of ripe tomatoes.

In human rights discourse and feminist discourse, metaphors of 'voice' are prevalent, but there is also a pervasive discourse of visuality. Human rights abuses are 'unveiled', 'made visible', 'revealed'. ${ }^{47}$ In discussion of gendered human rights, the veiled woman has become a privileged signifier of otherness and oppression, and the unveiling of the woman to reveal her face has become an over-determined signifier. In choosing the metaphor of 'face', then, the book also threatens to invoke the anxieties invoked in the first world viewer by the sight of the veiled woman, and the pleasure invoked in the first world viewer when the face of such a woman is 'unveiled' or 'revealed'. 'Face', then, is more than a neutral metaphor for individuality or personality.

Several of the photographs in this volume indeed invoke the trope of veiling and unveiling, such as a photograph of an Afghan woman, lightly veiled but revealing her face, sitting in front of a microphone in a radio studio (Figure 4): 


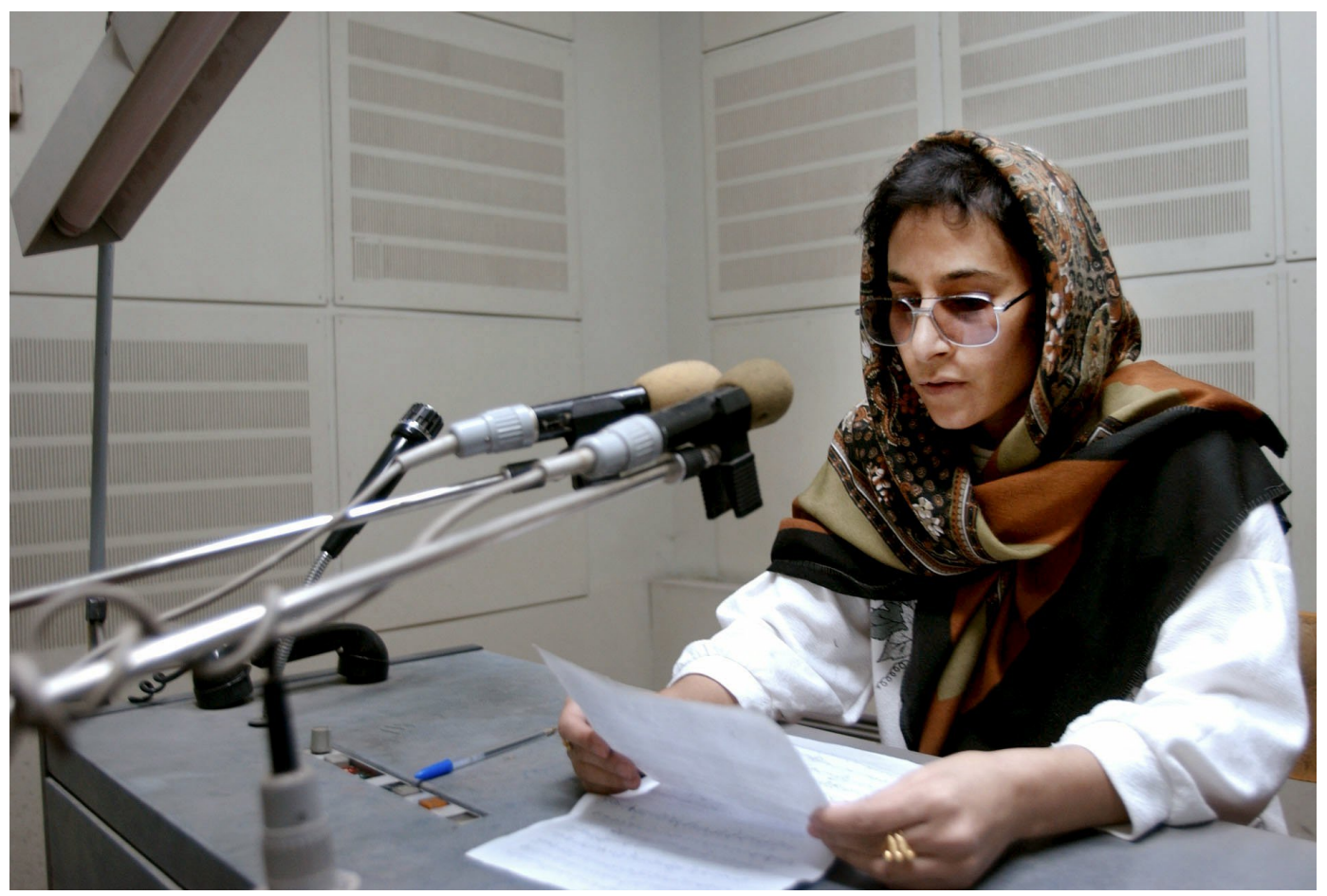

Figure 4: Marco di Laura, Afghanistan Women at Work, 2001

Source: Reproduced with permission of AAP Newswire Multimedia

AFGHANISTAN, Kabul, November 2001 Parveen Hashafi reads a newscast at Radio Afghanistan. Hashafi, who was auditioning for a newsreader's job, said she felt like a woman without a life during the Taliban Rule. Marco di Lauro. 48

While this is at first sight simply a realist, documentary photograph, any twenty-first century first world viewer is likely to make intertextual links with the overwhelming wave of photographs of newly unveiled Afghan women in the wake of the invasion of Afghanistan, and the persistent linking of national 'liberation' and the unveiling of women. The date of the photograph, November 2001, and the reference to the former Taliban regime invoke the narrative of US 'liberation' of Afghan women.

This is a particularly dense image, which manages to simultaneously invoke the metaphors of voice, face, veiling and unveiling. It seems she has been bestowed with both a 'face' and a 'voice'. Nevertheless, the photograph does not actually allow the viewer a sense of connectedness with the woman in the picture. Her head is cast down, looking at the script she is reading, so that she does not engage the gaze of the 
viewer. Rather, the first world viewer is interpellated as a spectator of the liberation of this third world woman.

In another photograph, an un-named young woman wears a veil which hides her hair but reveals her face. Painted on her forehead are red, white and blue bands of the French tricolore flag; on her cheeks are the words 'liberté' and 'égalité. She looks directly at the camera; her mouth is open as if she is perhaps chanting a political slogan. She is participating in a demonstration against the French government's banning of 'religious symbols' in schools (Figure 5).49 The first image appears in a section on political rights and freedom of expression; the second appears in a section on freedom of thought and belief. The women are portrayed as citizens exercising their rights to freedom of speech. The viewer is positioned slightly differently by each photograph, though, depending on whether or not we

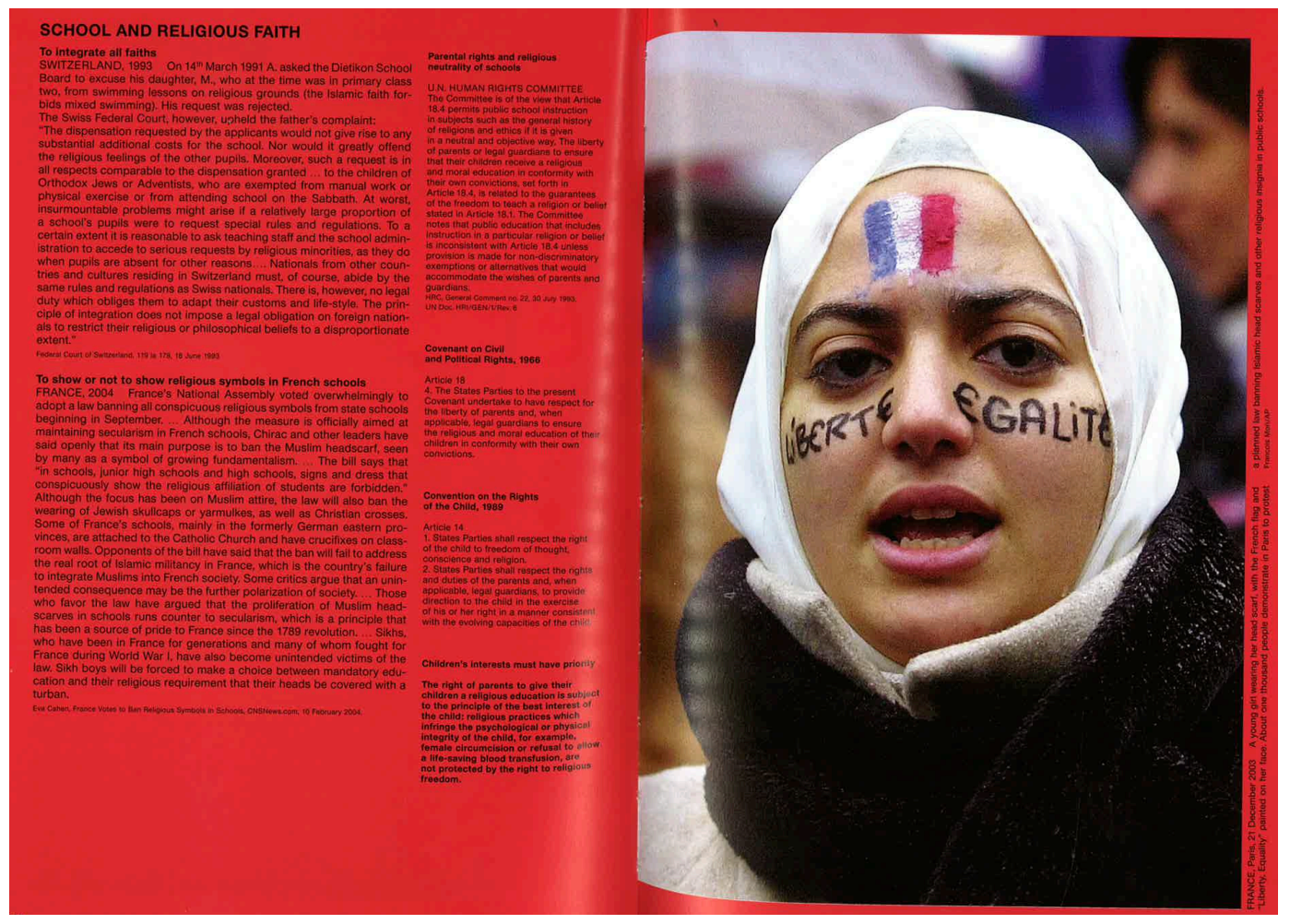

Figure 5: François Mori, France, Headscarves

Source: Double-page spread from Walter Kälin, Lars Müller and Judith Wyttenbach (eds), The Face of Human Rights, pp. 418-9; reproduced with permission of Lars Müller Publishers and AAP Newswire Multimedia 
have the illusion of meeting the photographic subject's gaze. Each image also works through its positioning in a series of over four hundred photographs over 700-odd pages, and its intertextual links with other images encountered by the reader before opening the book..$^{50} \mathrm{~A}$ photograph, then, can be read in several ways: through an engagement with its content as an isolated image, through its juxtaposition with text and paratext, through its placement in a series, through its intertextual links with other images and texts, and in a longer genealogy of similar representations.

-THE ETHICS OF DISPLAY AND THE POLITICS OF ADDRESS

In the section on the right to privacy, discussion of the prevalence of closed circuit cameras and other forms of surveillance and the articulation of the threat of 'having your picture recorded more than 300 times a day ${ }^{51}$ seems to bring into question the whole project of visualising human rights. Indeed, one wonders how most of these photographs were obtained, such as the photograph of two women in a brothel in Bombay. The caption reports that '[in] the brothels young prostitutes are exposed in cages to attract customers, many of them delivered by human traffickers or sold by their parents or husbands'. If these women, as suggested, are in the brothels in unfree conditions, did they have the opportunity to consent to be photographed? Similarly, if we wish to criticise their being 'exposed in cages to attract customers', what attitude should we take to the National Geographic photographer who took the photographs, and the book editors who reproduced their photograph yet again? ${ }^{52}$ What are the ethics of showing and looking in this case?

On reading and looking at the book, one is reminded of longstanding debates on the ethics and the efficacy of using photographs of atrocities. These issues are not canvassed explicitly, except for a brief excerpt from Susan Sontag's Regarding the Pain of Others: 'There's nothing wrong with standing back and thinking. To paraphrase several sages: "Nobody can think and hit someone at the same time."'53

Kälin, Müller and Wyttenbach's use of photographs can thus to some extent be placed in the context of a longstanding philosophical debate about what has been called the 'politics of pity', which dates back to Enlightenment thinkers such as Adam Smith. It can also be situated in the context of those who have discussed the use of photographs in political campaigns, such as Virginia Woolf in Three Guineas, Susan Sontag in On Photography and Regarding the Pain of Others, and Judith Butler 
in Frames of War. $^{54}$ Several modes of address have been identified in the representation of suffering: the mode of denunciation aims to stir up feelings of anger vis-á-vis the evil-doer who inflicted pain on the sufferer; the mode of philanthropy aims to activate feelings of tender-heartedness and actions to comfort the sufferer; while the mode of sublimation prompts reflection on the conditions of human misery. ${ }^{55}$ All of these modes of address can be inferred in The Face of Human Rights: denunciation of human rights abuses, a spur to action through the provision of information about the international human rights machinery, and reflections on the human condition through the series of images of children playing and studying, couples in wedding ceremonies, citizens demonstrating or families mourning those who have been 'disappeared'.

More recently, Wendy Hesford has treated visual representation as a form of rhetoric. ${ }^{56}$ She argues for a shift 'from uncritical consumption practices to interpretive practices that acknowledge the different axes of domination and shifting relations among [people] in diverse locations' ${ }^{57}$ Hesford's focus on rhetoric suggests the responsibility of 'rhetors', those who deploy particular rhetorical modes of address.

What is interesting about Kälin, Müller and Wyttenbach's volume is that photographs depicting 'the politics of pity' are probably not the majority of the visual representations in the book. Photographs of trauma are overweighed by photographs depicting what they call 'the enjoyment of human rights', defined as 'life in freedom and dignity, in its full richness and across cultures'. ${ }^{58}$ As scholars, we have perhaps spent more time documenting and analysing 'the politics of pity' than articulating what it would mean to 'visualise' all the 'dimensions of human rights'. The producers of The Face of Human Rights, while perhaps rather naïve in their deployment of visual imagery, challenge us to think through what is stake in attempting to visualise human rights. In addition to analysing the images themselves, it is also, however, necessary to consider how the viewer is being positioned and, indeed, what kind of viewer is being addressed.

The Face of Human Rights is an expensive hardback book which appeared in English-language and German-language editions. I purchased my copy in an Australian bookshop for AU\$85. Amazon.com lists a price of US\$60, but discounted to US\$42.36. This suggests a relatively wealthy first-world audience, with perhaps a 
wider audience of those who have access to libraries. The use of the English language suggests a wide global audience, but there do not seem to be any editions in non-European languages. The text also requires a high level of literacy. While the extensive use of photographs might suggest some accessibility to those without high-level literacy skills in English, it is difficult to see what would be communicated by the photographs to a viewer who did not have a good understanding of the text or some facilitation by a teacher, NGO worker or other intermediary.

The readers and viewers of this volume are positioned as having a global view, their spectatorship facilitated by the global media organisations, press agencies and photographic agencies whose photographs are displayed. These images have thus largely been filtered through the protocols of these agencies before they were selected by the editors of this volume. In many ways, then, the reader and viewer is positioned in a similar manner to the reader of Time Magazine, Life Magazine or the National Geographic, despite the different textual frame provided by the extensive discussion of human rights treaties and conventions.

\section{-CONCLUSIONS}

I am raising issues about the use of visual representation in The Face of Human Rights not in order to reject the strategy of visualisation, but rather to suggest that we need to take care in how we choose to communicate messages about human rights violations and how we choose to stimulate action and advocacy. Given the huge literature in cultural studies, semiotics and rhetorical studies which is available in order to consider the ways of communicating in diverse verbal and visual means, it would be a pity if the authors of such well-meaning texts as this were not able to take advantage of such reflexivity. It seems to me that it is not enough simply to 'show' and 'tell'.59 Rather, we need a more sophisticated understanding of the workings of verbal and visual texts, whether we communicate from the position of activists, academics, bureaucrats, educators, journalists or stakeholders. Questions of communication and representation cannot simply be ignored, in the hope that goodwill is enough. Much attention has been focused on the machinery of translation in a literal sense. International organisations like the United Nations and its agencies have developed sophisticated technical tools for simultaneous interpreting, and employ highly trained interpreters and translators 
for the purposes of translating between (selected) national languages in official meetings. ${ }^{60}$ Perhaps we also need to turn our attention to other aspects of communication, such as the question of how to translate between different frames of meaning, and the efficacy of different modes of communication with verbal and visual messages.

In this essay, I have analysed a text which attempts to communicate about human rights issues through a combination of verbal and visual means. I have tried to convey the embodied experience of reading and looking at this volume, through analysing my encounters with selected photographs and selected series of photographs. I have argued that photographs can be read in several ways: through an engagement with each photograph as an isolated image, through its juxtaposition with text and paratext, through its serial placement and juxtaposition with other images, through intertextual links with other images and texts, and in a longer genealogy of similar representations. Finally, each representation or group of representations needs to be placed in history. Sometimes history is referenced in the provision of captions and other paratextual information by the editors of The Face of Human Rights. In many other cases, the reader needs to look elsewhere to fill in the missing history and reflect on their own position in this history.

Vera Mackie is Senior Professor of Asian Studies in the Faculty of Law, Humanities and the Arts at the University of Wollongong. She is co-editor (with Mark McLelland) of the Routledge Handbook of Sexuality Studies in East Asia (2014) and co-editor (with Andrea Germer and Ulrike Wöhr) of Gender, Nation and State in Modern Japan (2014).

\section{-ACKNOWLEDgemEnTS}

This article draws on research conducted as part of an Australian Research Council-funded Future Fellowship Project (FT0992328), and draws on papers presented at the University of British Columbia, the National University of Singapore, the University of Wollongong and the University of Canberra. 
Thanks to Paul Rae for suggesting the title; and thanks to Anni Dugdale, Sneja Gunew, Paul Magee, Wenche Ommundsen, Paul Rae and Paul Sharrad for comments and feedback. I am also indebted to the editors of Cultural Studies Review and the anonymous reviewers for their comments. Alexander Brown assisted with obtaining copyright permissions.

\section{-NOTES}

${ }^{1}$ See $<$ https://unp.un.org/bookshop/default.aspx>. For illustrated children's editions of the Universal Declaration of Human Rights, see, inter alia, Ruth Rocha and Otavia Roth, Universal Declaration of Human Rights: An Adaptation for Children, United Nations Publications, New York, 1990; Amnesty International, We are all Born Free Mini Edition: The Universal Declaration of Human Rights in Pictures, Frances Lincoln Children's Books, London, 2011; United Nations, Declaration Universelle des Droits de l'Homme, United Nations, New York.

2 Walter Kälin, Lars Müller and Judith Wyttenbach (eds), The Face of Human Rights, Lars Müller Publishers, Baden, 2004.

${ }^{3}$ Gayatri Chakravorty Spivak, 'Three Women's Texts and Circumfession' in Postcolonialism and Autobiography, eds Alfred Hornung and Ernstpeter Ruhe, Editions Rodopi, Amsterdam, 1998, p. 7; Leigh Gilmore, The Limits of Autobiography: Trauma and Testimony, Cornell University Press, Ithaca, 2001, p. 3; Sidonie Smith and Julia Watson, 'Introduction' in Getting a Life: Everyday Uses of Autobiography, eds Sidonie Smith and Julia Watson, University of Minnesota, Minneapolis, 1996, p. 10; Kay Schaffer and Sidonie Smith, Human Rights and Narrated Lives: The Ethics of Recognition, Palgrave Macmillan, New York, 2004, passim.

${ }^{4}$ Caroline Turner and Nancy Sever (eds), Witnessing to Silence: Art and Human Rights, Drill Hall Gallery and Humanities Research Centre, ANU, Canberra, 2003, available at <http://www.anu.edu.au/hrc/research/WtoS/>; Wendy Hesford, 'Cosmopolitanism and Feminist Geopolitical Rhetorics' in Rhetorica in Motion, eds Eileen Schell and Kelly Rawson, University of Pittsburgh Press, Pittsburgh, 2010, pp. 53-70; Paul Rae, Theatre and Human Rights, Palgrave Macmillan, London, 2009; Meg McLagan, 'Principles, Publicity, and Politics: Notes on Human Rights Media', American Anthropologist, vol. 105, no. 3, 2003, pp. 605-12; Sarah Joseph, 'Social Media, Political Change and Human Rights', Boston College International and Comparative Law Review, vol. 35, no. 1, 2012, pp. 145-88.

${ }^{5}$ Sara Mills, Discourse, Routledge, London, 1997; Norman Fairclough, Critical Discourse Analysis, Longman, London, 1995; Alison Lee and Cate Poynton (eds), Culture and Text: Discourse and Methodology in Social Research and Cultural Studies, Allen and Unwin, Sydney, 2000.

${ }^{6}$ On the methodologies of 'reading' visual texts, see, inter alia, Norman Bryson, Michael Ann Holly and Keith Moxey (eds), Visual Culture: Images and Interpretations, University Press of New England for Wesleyan University Press, Hanover, 1994; Hal Foster (ed.), Vision and Visuality, Bay Press, Seattle, 1988; Gunther Kress and Theo van Leeuwen, Reading Images: The Grammar of Visual Design, Routledge, 
London and New York, 1996; Susan Sontag, On Photography, Penguin, Harmondsworth, 2002 [1977]; Susan Sontag, Regarding the Pain of Others, Farrar, Straus and Giroux, New York, 2003. See also, Vera Mackie, 'The Afghan Girls: Media Representations and Frames of War', Continuum, vol. 26, no. 1, 2012, pp. 115-31, where I propose a discursive and genealogical method for reading visual texts.

${ }^{7}$ I am thinking of such books as Steve McCurry's Portraits, Phaïdon, London, New York, 1999.

${ }^{8}$ Kälin, et al. The Face of Human Rights, pp. 8-9.

9 One hundred and sixty-three of the photographers were from the United States, and many of the photographs were sourced from the major photographic agencies, such as Magnum. The Face of Human Rights also uses photographs sourced from photographic agencies like Magnum and the major international press agencies. The quote comes from Edward Steichen, 'Introduction' in Museum of Modern Art, The Family of Man, Museum of Modern Art, New York, 1955, p. 3. (I have referred to the thirtieth anniversary edition of 1986 [12th printing, 2010].)

${ }^{10}$ Roland Barthes, 'The Great Family of Man', in Mythologies, Paladin, London, 1973 [1957], pp. 107-10, selected and translated by Annette Lavers. For a survey of the critiques of 'The Family of Man', see Fred Turner, 'The Family of Man and the Politics of Attention in Cold War America', Public Culture, vol. 21, no. 4 , p. 56 , note 2 .

${ }^{11}$ Barthes, 'The Great Family of Man', p. 107.

12 Ibid., p. 108.

${ }^{13}$ On the ethics of display, see Mackie, 'The Afghan Girls', pp. 126-7.

14 'The Family of Man' was displayed at the Museum of Modern Art from January to May 1955. Emmet Till was murdered in August 1955. His murderers were acquitted, but admitted to the killing in a magazine interview in 1956. The exhibition travelled to Paris in 1956, so the story of Emmet Till would have still been fresh in Barthes' mind.

15 Turner, 'The Family of Man', p. 84

${ }^{16}$ Kälin, et al. The Face of Human Rights, pp. 8-9.

${ }_{17}$ Edward Steichen, 'The Museum of Modern Art and "The Family of Man"' in A Life in Photography, Doubleday, New York, 1963; cited in Turner, 'The Family of Man', p. 59.

${ }^{18}$ We might note that 'man' can no longer be used in its supposedly generic and gender-neutral meaning in the early twenty-first century.

${ }^{19}$ An important juncture in the New York exhibition is an image of the mushroom cloud of a nuclear explosion, while one of the final images is of the United Nations building in New York (completed three years earlier in 1952). Turner, 'The Family of Man', p. 80.

${ }^{20}$ Samuel Moyn argues that it is only in the latter decades of the twentieth century that the discourse of 'human rights' became dominant in international affairs. Samuel Moyn, The Last Utopia: Human Rights in History, The Belknap Press, Cambridge, MA, 2010.

${ }^{21}$ Ryszard Kapuscinski, The Emperor, Harcourt, Brace, Jovanovich, 1983 [1982], translated by William R. Brand and Katarzyna Mroczkowska-Brand; Sontag, Regarding the Pain of Others. 
22 This is in contrast to Nicholas D. Kristof and Sheryl WuDunn's Half the Sky: Turning Oppression into Opportunity for Women Worldwide, Alfred Knopf, New York, 2009, where human rights issues are almost totally externalised. See my analysis in Vera Mackie, 'The Cultural Dimensions of Human Rights Advocacy in the Asian Region' in Crises and Opportunities: Proceedings of the 18th Biennial Conference of the ASAA, eds Elizabeth Morrell, and Michael D. Barr, Asian Studies Association of Australia (ASAA) Inc and the University of Adelaide, Adelaide, 2010, available at <http://asaa.asn.au/ASAA2010/reviewed_papers/Mackie-Vera.pdf>.

${ }^{23}$ A 'holy union' is defined here as a 'marriage not recognised by the state'.

${ }^{24}$ Kälin, et al. The Face of Human Rights, pp. 138-9.

25 Ibid., pp. 8-9.

${ }^{26}$ A. Byrnes, et al., Bills of Rights in Australia: History, Politics and Law, UNSW Press, Sydney, 2009, p. 16.

${ }^{27}$ Kälin, et al. The Face of Human Rights, pp. 6-7.

28 Sima Samar, 'Visualizing Women's Health Care in Afghanistan', in The Face of Human Rights, ed. Kälin, et al., pp. 178-81.

${ }^{29}$ Kälin, et al., The Face of Human Rights, pp. 430-69.

${ }^{30}$ Kälin, et al., The Face of Human Rights, pp. 346-53. The reader might be reminded of a similar series of wedding photographs in the 'The Family of Man': see MOMA, The Family of Man, pp. 14-17; these are from Japan, Czechoslovakia, India, Sweden, the United States of America, France and Mexico.

${ }^{31}$ Kälin, et al., The Face of Human Rights, pp. 138-9.

32 Barthes, 'The Great Family of Man', p. 109.

${ }^{33}$ Kälin, et al., The Face of Human Rights, pp. 658-9.

34 Ibid., pp. 3, 11.

${ }^{35}$ Ibid., pp. 74-5, 3. The photographs in this section of the book on 'the right to life' are placed on pages with a blood-red border, and the text refers to the death penalty, abortion, extra-judicial executions, death in custody and terrorism.

${ }^{36}$ See also the depiction of a shooting in East Timor on pp. 52-3, with the caption 'EAST TIMOR, 26 August 1999 Bernardino Guterres was killed in East Timor by Indonesian forces. This occurred four days before East Timor's vote for independence from Indonesia'.

${ }^{37}$ Kälin, et al., The Face of Human Rights, pp. 347-353, 430-69.

38 Ibid., p. 45.

${ }^{39}$ Ibid., p. 47.

40 Ibid., pp. 48-9.

${ }^{41}$ Ibid., p. 73. See also the series of photographs in the section on torture, which depict a room with a bare bed frame and shackles, garrottes and various implements used for torture in a cell in the former Yugoslavia, pp. 573-4.

42 Ibid., p. 139. 
${ }^{43}$ The images which do not directly depict individual people in The Face of Human Rights include the scenes of empty death chambers, torture chambers and graveyards.

${ }_{44}$ While the individuals in photographs are often un-named, photographers or copyright holders are always named.

45 In the German edition, the word used is 'bild', which connotes 'picture, photograph, image, drawing, painting, figure': Walter Kälin, Lars Müller and Judith Wyttenbach (eds), Das Bild der Menschenrechte, Lars Müller Publishers, Baden, 2004.

${ }^{46}$ Both quotes are from Carl Sandburg, 'Prologue', in Museum of Modern Art, The Family of Man, pp. 45.

${ }^{47}$ Note, for example, the following titles: Cheryl Benard, Veiled Courage: Inside the Afghan Women's Resistance, Random House, Sydney, 2002; 'Beneath the Veil: Inside the Taliban's Afghanistan', 2001, <http://www.cnn.com/CNN/Programs/presents/index.veil.html>; Geraldine Brooks, Nine Parts of Desire: The Hidden World of Islamic Women, Anchor, New York, 1995; Frantz Fanon, 'Algeria Unveiled', in Studies in a Dying Colonialism, Grove Press, New York, 1965 [1957]; Charles Forster,

Mohammetanism Unveiled, A.R. Spottiswoode, London, 1829, in 2 volumes; 'Free to Lift the Veil', International Herald Tribune (Tokyo Edition), 15 November 2001, p. 1; Jan Goodwin, Price of Honour: Women Lift the Veil of Silence on the Islamic World, Plume, London, 2002 [1995]; Latifa, My Forbidden Face: Growing Up under the Taliban: A Young Woman's Story', Virago, London, 2002; Harriet Logan, Unveiled: Voices of Women in Afghanistan, Regan Books, New York, 2002; Steve McCurry, 'I Could See her Eyes through the Camera Lens. They're Still the Same', National Geographic, April 2002, np; Fatima Mernissi, Beyond the Veil, Schenkmann, Cambridge, MA, 1975; Cathy Newman, 'A Life Revealed', National Geographic, April 2002, np, special report with photographs by Steve McCurry, 2002; Kay Rasool, My Journey Behind the Veil: Conversations with Muslim Women, Lothian Books, Melbourne, 2002; Reuters, Afghanistan: Lifting the Veil, Prentice Hall, New York, 2002; Deborah Rodriguez and Kristin Ohlson, Kabul Beauty School: An American Woman Goes behind the Veil, Random House, New York, 2007; John Stanmeyer, 'Photoessay: Kabul Unveiled', 2001,

<www.time.com/time/photoessays/afghanwomen/8.html>; Amy Waldman, 'Women Unveil Their Secret Defiance', International Herald Tribune, 20 November 2001, p. 3; Ruth Francis Woodsmall, 'Lifting the Veil', in Woman in the Changing Islamic System, BILMA Publishing House, Delhi, 1983 [1936]; Batya Swift Yasgur, Behind the Burqa: Our Life in Afghanistan and How We Escaped to Freedom, Wiley, Hoboken, 2002.

${ }^{48}$ Kälin, et al. The Face of Human Rights, pp. 628-9.

49 Ibid., pp. 418-9.

${ }^{50}$ See my analysis of such photographs in Mackie, 'The Afghan Girls', pp. 115-131.

${ }^{51}$ Kälin, et al., The Face of Human Rights, p. 320.

52 Ibid., pp. 480-1.

${ }^{53}$ Susan Sontag, 'Regarding the Pain of Others', in Kälin, et al., The Face of Human Rights, pp. 564-5. 
54 Virginia Woolf, Three Guineas, Penguin, Harmondsworth, 1977 [1938]; Sontag, On Photography; Sontag, Regarding the Pain of Others; Judith Butler, Frames of War: When is Life Grievable?, Verso, London, 2009, pp. 63-100.

${ }^{55}$ Lilie Chouliaraki, The Spectatorship of Suffering, Sage, London, 2006, p. 81; Luc Boltanski, Distant Suffering: Morality, Media and Politics, Cambridge University Press, Cambridge, 1999.

${ }_{56}$ Wendy Hesford, Spectacular Rhetorics: Human Rights Visions, Recognitions, Feminisms, Duke University Press, Durham, 2011.

${ }^{57}$ Hesford, 'Cosmopolitanism and Feminist Geopolitical Rhetorics', p. 70.

${ }^{58}$ Kälin, et al. The Face of Human Rights, pp. 8-9.

${ }_{59}$ Julie Stephens, “'Show and Tell”: Writing on Third World Women', Arena, No 88, 1989, pp. 167-72.

See also: Chandra Talpade Mohanty, 'Under Western Eyes: Feminist Scholarship and Colonial Discourses', in Third World Women and the Politics of Feminism, ed. Mohanty et al., pp. 51-80; Gayatri Chakravorty Spivak, 'Three Women's Texts and a Critique of Imperialism' in 'Race', Writing and Difference, ed. Henry Louis Gates, Jr., Chicago University Press, Chicago, 1985, pp. 262-80; Julie Stephens, 'Feminist Fictions: A Critique of the Category "Non-Western Woman" in Feminist Writings on India', in Subaltern Studies VI, ed. Ranajit Guha, Delhi, Oxford University Press, 1989.

${ }^{60}$ Nevertheless, see Naoki Sakai's critical view of the 'necessity' and 'impossibility' of translation. Sakai cautions against a naïve view of the possibility of adequate and transparent translation between languages. Naoki Sakai, 'Introduction', Traces, no 1, 2001, p. x. 